\title{
Research on the Construction of Intelligent Comprehensive Training Room of Cross-border Electronic Commerce
}

\author{
GU ShanYu, a , LIU Xiao ${ }^{2, b}$, LI Bing ${ }^{2, b}$ \\ 1,2Guangxi Vocational and Technical College of Communications, Guangxi, Nanning, postcode 530001 \\ a,b61220928@qq.com
}

Keywords: Open-type; Cross-border electronic commerce; Training; Teaching model

\begin{abstract}
There are new requirements and also new chances for training of e-commerce and international trade because of the rapid development of cross-border e-commerce and the shortage of cross-border e-commerce professionals. Open-type training model of cross-border e-commerce relies on actual combat-based training courses, and then they can be used as a transition between training and enterprise practice in order to improve the competitiveness of students and employments.
\end{abstract}

\section{Introduction}

In recent years, the rise of cross-border e-commerce has brought development opportunities for the transformation and upgrading of China's traditional foreign trade enterprises. In this process, the demand of enterprises for cross-border e-commerce talents also gradually increases. At present, there are many relatively mature cross-border e-commerce platforms such as AliExpress, DHgate and Amazon, which can be taken fully advantages of to carry out professional training in teaching reform.

\section{Teaching plans of intelligent comprehensive training room of cross-border electronic commerce}

A.Training objects. On the real cross-border e-commerce platform, we set up training contents such as opening business cross-border e-commerce stores, operation management and other tasks, through teaching model of teaching, learning and doing to complete the teaching task.

B.Training contents. In accordance with the real store management processes of cross-border e-commerce platform, we have five major training projects such as online stores design, product management, marketing, logistics management and online customer service, and each sub-tasks have corresponding practical content (see Table 1).

Table 1 Training projects setting of open cross-border e-commerce

\begin{tabular}{|c|c|c|}
\hline Training projects & training tasks processes & specific training contents \\
\hline \multirow{3}{*}{ Online store } & Knowing platforms & $\begin{array}{c}\text { Be familiar with the rules of the } \\
\text { platform }\end{array}$ \\
\cline { 2 - 3 } & Store registration and certification & $\begin{array}{c}\text { To register on the platform and } \\
\text { compete the certification }\end{array}$ \\
\cline { 2 - 3 } & Cross-border payment & $\begin{array}{c}\text { To open cross-border payment } \\
\text { channels }\end{array}$ \\
\hline $\begin{array}{c}\text { product } \\
\text { management }\end{array}$ & Selecting products & $\begin{array}{c}\text { How to select products on } \\
\text { different platforms }\end{array}$ \\
\hline
\end{tabular}




\begin{tabular}{|c|c|c|}
\hline & Products release & $\begin{array}{l}\text { Product photography and image } \\
\text { processing skills }\end{array}$ \\
\hline & Pricing strategies & Methods of pricing \\
\hline \multirow{3}{*}{ marketing } & Shop decoration & $\begin{array}{c}\text { Basic operation of platform } \\
\text { decoration }\end{array}$ \\
\hline & Keywords optimization & Keywords analysis \\
\hline & Promotional activities & $\begin{array}{l}\text { Independent marketing, paying } \\
\text { promotion and other methods }\end{array}$ \\
\hline \multirow{2}{*}{$\begin{array}{l}\text { logistics } \\
\text { management }\end{array}$} & Freights setting & $\begin{array}{l}\text { International logistics freight } \\
\text { standards }\end{array}$ \\
\hline & Orders processing & $\begin{array}{c}\text { Methods and tactics of orders } \\
\text { processing }\end{array}$ \\
\hline \multirow{3}{*}{$\begin{array}{l}\text { online customer } \\
\text { service }\end{array}$} & management inquiries & $\begin{array}{l}\text { Foreign trade communication } \\
\text { skills }\end{array}$ \\
\hline & After-sales services & customer relation management \\
\hline & Disputes handling & Crisis public relations \\
\hline
\end{tabular}

C. Training implementation. According to training tasks, the training will be divided into three stages. The first phase: grouping students to form a project team, under the guidance of the teacher, the division of team members should be divided and the team leader should be selected. The second stage: each team should register stores on the real cross-border e-commerce platforms and finish related stores certification. The third stage: each team should upload products information, finish related settings and carry out the promotion work according to the group task distribution. Students should complete training tasks at all stages under the guidance of teachers, in the processes, if there is no order, the orders processing and customers service for some tasks can temporarily stop. Students take positions of selection, marketing, international logistics, online customer services and other positions in rotation in order to get the abilities of operation skills and teamwork skills.

D. Training assessment. This training is mainly based on the team assessment. Taking the performance of the business as the main evaluation index of the team, at the same time, the teacher can make appropriate addition and subtraction scores according to the cooperations among the team members in order to emphasize the team spirit.

\section{Platform of intelligent comprehensive training room of cross-border e-commerce}

With the continuous improvement of computer network technology and the rise of the Internet and mobile Internet, there are also many internet-based e-commerce entrepreneurship training platforms on the market. These platforms can be both for individuals and schools, and are WEB system of B / S architecture, so students can log in to the platform anytime and anywhere. There are rhree representative Internet e-commerce training platforms for analysis of advantages and disadvantages in table 2.

Table 2 Comparative Analysis of cross-border e-commerce training platform

\begin{tabular}{|c|c|c|c|}
\hline $\begin{array}{c}\text { Jin Malan } \\
\text { entreprene } \\
\text { urial } \\
\text { training } \\
\text { long-distan } \\
\text { ce platform }\end{array}$ & $\begin{array}{c}\text { Advantag } \\
\text { es }\end{array}$ & $\begin{array}{l}\text { 1. Remote platform, you can log in through the Internet without site } \\
\text { restrictions; } \\
\text { 2. More auxiliary modules, the students can get reasonable assessments } \\
\text { before they starting their own business; } \\
\text { 3. It aims at entrepreneurship process and has newer entry point; } \\
\text { 4. It provides online survey exams and consulting. }\end{array}$ \\
\hline
\end{tabular}




\begin{tabular}{|c|c|c|}
\hline & $\begin{array}{l}\text { Disadvant } \\
\text { ages }\end{array}$ & $\begin{array}{l}\text { 1.Less functions; } \\
\text { 2.It didn’t provide users with the initiative to register the entrance; } \\
\text { 3.There are less legal liability forms, which is only four of them; } \\
\text { 4.Too much information to fill in. }\end{array}$ \\
\hline \multirow{2}{*}{$\begin{array}{l}\text { Campus } \\
\text { E-commerc } \\
\text { e training } \\
\text { platform }\end{array}$} & $\begin{array}{l}\text { Advantag } \\
\text { es }\end{array}$ & $\begin{array}{l}\text { 1.Using complete open network without installment and support of touch } \\
\text { screen; } \\
\text { 2.Focusing on the direction of e-commerce, which is new innovative } \\
\text { direction; } \\
\text { 3.There are real transactions because real business can participate; } \\
\text { 4.It has better operating environment support for operation, for example, it } \\
\text { provides technical support services for WeChat shop. }\end{array}$ \\
\hline & $\begin{array}{l}\text { Disadvant } \\
\text { ages }\end{array}$ & $\begin{array}{l}\text { 1.The target customers are vocational students, which is narrow positioning; } \\
\text { 2. Currently, there are not many colleges and universities using this system } \\
\text { and the promotion work is not done yet; } \\
\text { 3.The current registered user is not active, the system can not really be used; } \\
\text { 4. There are still some bugs in the website; } \\
\text { 5. Since it is a purely network system, there is limited help given by the } \\
\text { teacher during use. }\end{array}$ \\
\hline \multirow{2}{*}{$\begin{array}{c}\text { Ying Dong } \\
\text { distribution } \\
\text { platform }\end{array}$} & $\begin{array}{c}\text { Advantag } \\
\text { es }\end{array}$ & $\begin{array}{l}\text { 1. It is built relying on Taobao and the ninth e-commerce contest of } \\
\text { Zhejiang Province; } \\
\text { 2. There are comprehensive commodities and adequate Taobao data support } \\
\text { for the platform; } \\
\text { 3. There are practical and real channels for goods sales; } \\
\text { 4. Website operation and maintenance is better and it has been updated. }\end{array}$ \\
\hline & $\begin{array}{l}\text { Disadvant } \\
\text { ages }\end{array}$ & $\begin{array}{l}\text { 1.The system business is single, which is all business-oriented e-commerce } \\
\text { training; } \\
\text { 2.There are many distribution data packets and they are big ones and need } \\
\text { more time to organize. }\end{array}$ \\
\hline
\end{tabular}

The current training platform for this type of business mostly concentrated in the field of entrepreneurship and e-commerce, the reason is:

(1)A wide range of target people. In addition to students majoring in e-commerce, the students in other majors can also join the platform to start the business.

(2)It is easy to cut into with real entrepreneurs participation. College students can not only get exercises on these platforms, but also earn some money reward, which is attractive to students.

(3)Low trial-and-error cost. Because it is a pure Internet products and hardware investment is small, most of the cost comes from labor costs.

At present, the pure Internet training platform is still in the development stage. Due to the different functions of the three training platforms and the crowd it faces, its teacher management mode is naturally different. Table 3 is the comparison of management training model under three training platforms. 
Table 3 Comparison of management training model under three training platforms

\begin{tabular}{|c|l|}
\hline $\begin{array}{c}\text { Platform } \\
\text { types }\end{array}$ & \multicolumn{1}{c|}{ Training teachers management methods } \\
\hline $\begin{array}{c}\text { Traditional } \\
\text { school training } \\
\text { platforms }\end{array}$ & $\begin{array}{l}\text { Teachers are all staff in the school, in accordance with the traditional management of } \\
\text { teachers management approaches, we use researches, dissertations and other aspects of } \\
\text { teacher into our school, the functions of teachers management system are concentrated on } \\
\text { teacher information management, college information management, research paper } \\
\text { management and training management, which is not involved functions of teachers } \\
\text { assignments distribution or Q\&A records. }\end{array}$ \\
\hline $\begin{array}{c}\text { Individually-or } \\
\text { iented network } \\
\text { training } \\
\text { platform }\end{array}$ & $\begin{array}{l}\text { Because such platforms are individual-oriented, most teachers are online without school } \\
\text { intervene.Teachers are contracted staff on the website and not responsible for organizing } \\
\text { fixed training classes but recording teaching videos and answering questions of students, } \\
\text { and obtain appropriate remuneration according to their workload. The way teachers are } \\
\text { administered is similar to the way employees managing their business. }\end{array}$ \\
\hline $\begin{array}{c}\text { Internet } \\
\text { e-commerce } \\
\text { training } \\
\text { platform }\end{array}$ & $\begin{array}{l}\text { College teachers and business teachers are both involved. However, since the platforms } \\
\text { involve the contents of e-commerce and is closely related to students own interests, } \\
\text { teachers only play a role of getting started in previous lessons. The teacher's management is } \\
\text { similar to that of the traditional teachers management except that through the management } \\
\text { system, the teacher can check the current operation situations of the students in the training } \\
\text { process, but can not know in time if the students have encountered difficulties in the } \\
\text { operation process and can not record the students' difficulties for later reference, most of the } \\
\text { time it relies on the students to operate independently. }\end{array}$ \\
\hline
\end{tabular}

These three kinds of training platforms have a big deficit in the management of training teachers. From the functional point of view, the current platform has its own advantages and disadvantages. Compared with the traditional school training platforms, they have experienced a longer period of development, and the model of teachers management system are put forward to fix the deficiencies of traditional training platforms.

\section{Intelligent comprehensive training room of cross-border e-commerce; System design and implementation}

\section{A.System design}

The design of the system uses MVC three-tier architectures, in order to realize MVC three-tier architecture we use three main frameworks of Struts2, iBatis and Spring. The view tier uses JSP pages and through Ajax and jQuery technologies to realize partial refresh. The control tier controls logics by using the Action that inherits from the ActionSupport class in Struts2 to realize page jump and page data display. This system diagram is shown in Figure 1. Teachers and students information table records the basic information of teachers and students such as user names, login password and the corresponding schools. The detailed fields are shown in table 4 - table 6 .

Table 4 Teachers information (innerteacher)

\begin{tabular}{|c|c|c|c|}
\hline Fieldname & Data type & $\begin{array}{c}\text { Whether major } \\
\text { key/foreign key or not }\end{array}$ & Statements \\
\hline id & INT & Major key & Instructor ID \\
\hline username & VARCHAR & No & Usename \\
\hline password & VARCHAR & No & User password \\
\hline Usercode & VARCHAR & No & User ID \\
\hline
\end{tabular}




\begin{tabular}{|c|c|c|c|}
\hline schoolcode & VARCHAR & No & School ID \\
\hline School_id & $1 \mathrm{NT}$ & Foreign key & Corresponding school \\
\hline
\end{tabular}

Table 5 Students information (student)

\begin{tabular}{|c|c|c|c|}
\hline Fieldname & Data type & $\begin{array}{c}\text { Whether major } \\
\text { key/foreign key or not }\end{array}$ & Statements \\
\hline id & INT & Major key & ID \\
\hline username & VARCHAR & No & Usename \\
\hline password & VARCHAR & No & User password \\
\hline innerteacher_id & INT & Foreign key & Corresponding teacher \\
\hline
\end{tabular}

Table 6 School information (school)

\begin{tabular}{|c|c|c|c|}
\hline Fieldname & Data type & $\begin{array}{c}\text { Whether major } \\
\text { key/foreign key or not }\end{array}$ & Statements \\
\hline id & INT & Major key & School ID \\
\hline code & VARCHAR & No & School code \\
\hline name & VARCHAR & No & School name \\
\hline
\end{tabular}

\section{B.Client-side implementation}

Client-side APP is mainly operating on smart phones, tablets and other terminal equipments of college teachers. At present, the mainstream mobile device operating system is Android and IOS. Since the on-line process is complicated after the development of the IOS product, the system uses Android as an example. Android system consists of four parts, respectively, the underlying Linux kernel-based, the layer developed by the $\mathrm{C}$ language, is responsible for providing some basic functions; The middle layer developed by $\mathrm{C}++$, which contains the Library and the Dalvik virtual machine, is responsible for providing the API interface(APPLICATIONFRAMEWORK), this layer includes the various components and controls to develop the program; the top layer is the application layer, developers use the Java language to write their own applications. Android architecture diagram is the figure 1.

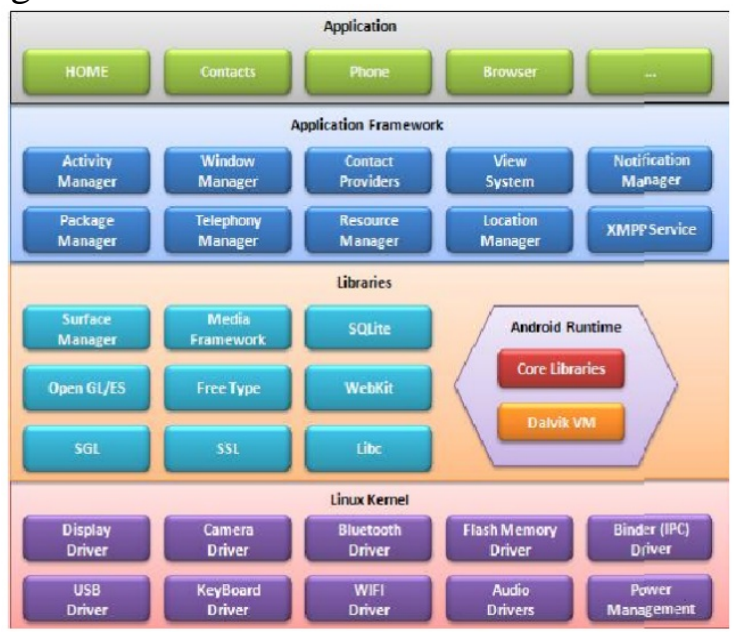

Figure 1 Android architecture diagram

C.Teacher incentive and performance system 
Table 7 is the assessment index weight table built according to the evaluation criteria. Teachers' basic salaries are recorded as SA, and teachers' performance salaries are formed by combining the performance scores of the index and their weights in Table 7 with the basic salaries Sa.

Table 7 Assessment index weight table

\begin{tabular}{|c|c|c|c|c|}
\hline & $\begin{array}{c}\text { Scores of teaching } \\
\text { hours }\end{array}$ & $\begin{array}{c}\text { Scores of } \\
\text { students }\end{array}$ & $\begin{array}{c}\text { scores of } \\
\text { teachers }\end{array}$ & Weights \\
\hline $\begin{array}{c}\text { Scores of teaching } \\
\text { hours }\end{array}$ & 1 & 2 & 2 & 0.5 \\
\hline Scores of students & $1 / 2$ & 1 & 1 & 0.25 \\
\hline scores of teachers & $1 / 2$ & 1 & 1 & 0.25 \\
\hline Total & 2 & 4 & 4 & 1 \\
\hline
\end{tabular}

The formula of teachers' wages calculation methods:

$$
S=S_{A}+S_{A} \cdot\left(\frac{0.5 . T_{a}+0.8 T_{b}+0.8 \cdot \frac{\sum_{c=1}^{n} T_{c}}{n}}{0}\right)
$$

\section{Conclusion}

Starting from the demand of enterprises for cross-border e-commerce talents and relying on the real cross-border e-commerce projects of enterprises, taking all major cross-border e-commerce platforms as training carriers and introducing innovative training evaluation and assessment mechanisms, we can improve the students' innovation and entrepreneurship and increase employment opportunities for the relevant professional students.

\section{References}

[1]Lv Hongjing. Research on the Implementing Teach-learn-do Amalgamation of Cross-border E-commerce Training Courses [J]. E-business Journal,2016,12:79-80.

[2]Li Rong. Optimizing Research on "Introducing Projects into Schools” to Jointly Build a Training Base in Colleges and Universities [J]. E-business Journal,2017,01:85-86.

[3]Lv Hongjing. Research on the Construction of Cross-border E-commerce Training Base with Entrepreneurial Orientation [J]. E-business Journal,2017,01:87-88.

[4]Zhong Yan, Yang Xiaohui. Influence of Cross-border E-commerce Training on Teaching Reform in Middle and Western Universities - Take International Trade Major of Hubei International Studies University as an Example [J]. Modern Business Trade Industry,2016,33:309-310.

[5]Hu Haiqing, Changjie. Research on Construction of Cross-border E-commerce Express Virtual Simulation Training System [J]. Experimental Technology and Management,2017,03:8-12. 